\title{
Sinus floor elevation and simultaneous implant placement in fresh extraction sockets: a systematic review of clinical data
}

\author{
Mehdi Ekhlasmandkermani ${ }^{1}$, Reza Amid ${ }^{1,2}$, Mahdi Kadkhodazadeh ${ }^{1,2}$, \\ Farhad Hajizadeh ${ }^{1}$, Pooria Fallah Abed ${ }^{3}$, Lida Kheiri', Aida Kheiri ${ }^{5}$ \\ ${ }^{1}$ Department of Periodontics, School of Dentistry, Shahid Beheshti University of Medical Sciences, \\ ${ }^{2}$ Dental Research Center, Research Institute of Dental Sciences, School of Dentistry, Shahid Beheshti University of Medical Sciences, Tehran, Iran, \\ ${ }^{3}$ Department of Periodontology, Texas A and M College of Dentistry, Dallas, TX, USA, \\ ${ }^{4}$ Department of Oral and Maxillofacial Surgery, School of Dentistry, Isfahan (Khorasgan) Branch, Islamic Azad University, Isfahan, \\ ${ }^{5}$ Student Research Committee, School of Dentistry, Shahid Beheshti University of Medical Sciences, Tehran, Iran
}

\begin{abstract}
J Korean Assoc Oral Maxillofac Surg 2021;47:411-426)
Combining different procedures to reduce the number of surgical sessions and patient discomfort in implant placement and sinus floor elevation has been recommended, and evidence supports good outcomes. The aim of this study was to review the results of clinical studies on sinus floor elevation through extraction sockets and simultaneous immediate posterior implant placement. An electronic search was carried out in PubMed, Scopus, and Web of Science to find English articles published in or before August 2020. A manual search was also performed. Titles, abstracts, and the full-text of the retrieved articles were studied. Thirteen studies met our eligibility criteria: 6 retrospective case series, 3 case reports, 2 prospective cohort caseseries, 1 prospective case series, and 1 randomized controlled trial. Overall, 306 implants were placed; 2 studies reported implant survival rates of $91.7 \%$ and $98.57 \%$. The others either did not report the survival rate or reported $100 \%$ survival. Sinus floor elevation through a fresh extraction socket and simultaneous immediate implant placement appears to be a predictable modality with a high success rate. However, proper case selection and the expertise of the clinician play fundamental roles in the success of such complex procedures.
\end{abstract}

Key words: Sinus floor augmentation, Sinus augmentation, Immediate dental implant, Sinus lift, Dental implantation

[paper submitted 2020. 11. 20 / revised 2021. 1. 6 / accepted 2021. 1. 21]

\section{Introduction}

Maxillary sinus floor pneumatization occurring after posterior maxillary tooth extraction can jeopardize straightforward implant placement ${ }^{1}$. Following tooth extraction and discontinuation of the blood supply provided by the periodontal ligament (PDL), the alveolar ridge undergoes resorption ${ }^{2}$. The physiological process of ridge resorption during the bone healing and remodeling phase ${ }^{3}$ and pneumatization of the maxillary sinus ${ }^{4}$ are important factors that affect the amount

\section{Reza Amid}

Department of Periodontics, School of Dentistry, Shahid Beheshti University of Medical Sciences, Daneshjou Boulevard, Evin, Tehran 1983969411, Iran TEL: +98-09124660495

E-mail:reza_amid@yahoo.com

ORCID: https://orcid.org/0000-0002-8053-3928

(c) This is an open-access article distributed under the terms of the Creative Commons Attribution Non-Commercial License (http://creativecommons.org/ licenses/by-nc/4.0/), which permits unrestricted non-commercial use, distribution, and reproduction in any medium, provided the original work is properly cited.

Copyright (C) 2021 The Korean Association of Oral and Maxillofacial Surgeons. of residual bone in the posterior maxilla. Both the quantity and quality of bone reflect the low density of bone in this region ${ }^{4}$, and any combination of the aforementioned factors can complicate dental implant placement in the posterior maxilla. Several approaches have been suggested to solve those problems ${ }^{5}$. Sinus floor elevation can be performed via the crestal and lateral approaches ${ }^{6-8}$. In 1976, Tatum was the first to describe the sinus floor elevation technique ${ }^{6}$, and the surgical approach for sinus floor elevation was published by Boyne and James in $1980^{7}$. Because the lateral approach is an invasive technique associated with significant postoperative discomfort, Summers ${ }^{8}$ proposed the use of osteotomes and the crestal approach in 1994, claiming that that approach solved the problems of limited bone quality and quantity in the posterior maxilla.

Accessing the Schneiderian membrane via the crestal approach and elevating it after entering the sinus cavity were modifications made over time, and in 2017, Pawar et al. ${ }^{9}$ discussed their efficacy. 
In the crestal approach for dental implant placement, the remaining bone height is what matters most in achieving primary stability ${ }^{10}$. Moraschini et al. ${ }^{11}$, in a comprehensive review in 2017, concluded that the remaining bone height is more important than the use or omission of graft materials and bone substitutes beneath the sinus membrane in the process of sinus lifting. Achieving primary implant stability is a common requirement of two of the most common implant surgeries: sinus floor elevation simultaneous with implant placement and immediate implant placement in fresh extraction sockets ${ }^{12}$.

The history of immediate implant placement in fresh extraction sockets dates back to 1976, when Schulte and Heimke $^{13}$ suggested the approach as a strategy to save time. Alveolar bone remodeling starts immediately after tooth extraction. Evidence shows that the process of bone resorption begins 14 days after tooth extraction and can involve more than $20 \%$ of the buccal cortical bone ${ }^{2}$. Thus, immediate implant placement saves time, eliminates the need for a second surgical procedure, and decreases patient discomfort and the cost of treatment ${ }^{14,15}$. Previous studies claimed that immediate implant placement could prevent alveolar bone collapse ${ }^{16}$, but recent investigations have shown that it only limits bone remodeling and can even result in more bone loss compared with early implant placement ${ }^{17,18}$. Immediately placed implants have lower survival and success rates than delayed implant placements ${ }^{19}$, and marginal bone loss and periimplant soft tissue changes are mentioned as shortcomings of immediate implant placement; however, there is a lack of data about the success/survival rate and marginal bone loss of delayed implant placements ${ }^{20}$.

In general, the posterior maxillary bone has a lower density than other parts of the jaw. Thus, achieving primary stability is more difficult, which could explain the lower success rate of immediate implants placed in the posterior maxilla compared with the mandible ${ }^{4,21}$. Given that the goal of implant treatment is functional reconstruction of the posterior maxilla, the treatment plan can include the extraction of hopeless teeth, time allocated for healing the extraction sockets, sinus floor elevation in a separate session via the lateral or crestal approach to increase bone height, and eventual implant placement. Alternatively, a treatment plan that condenses all of those procedures into a single session would be ideal for patients, with the benefit of a short course of treatment and fewer surgical procedures ${ }^{15}$.

Therefore, we extracted and reviewed the results of clinical studies about sinus floor elevation through the extraction socket and simultaneous, immediate implant placement.

\section{Materials and Methods}

This systematic review was conducted by following the principles of the PRISMA (Preferred Reporting Items for Systematic Reviews and Meta-Analyses) statement.

\section{Focused question (PICO)}

The focused question was: What are the differences among techniques presented for simultaneous closed sinus floor elevation with implant placement in fresh extraction sockets?

\section{Type of studies}

We included all human clinical studies of the immediate placement of implants in fresh extraction sockets in the posterior maxilla with sinus floor elevation via the same extraction sockets. The search was limited to English-language studies. Abstracts, letters, and reviews were excluded.

\section{Type of participants}

All patients who needed the extraction of a tooth/teeth in the posterior maxillary region, sinus floor elevation through the extraction socket(s), and immediate implant placement in the fresh socket(s) were included.

\section{Type of intervention}

Studies were included if they mentioned simultaneous closed sinus floor elevation with implant placement in fresh extraction sockets in the posterior maxillary region. Studies that did not perform sinus floor elevation through a fresh socket in the posterior maxilla or did not place implants immediately were excluded.

\section{Type of outcome measures}

The primary outcome was the survival/success rate of the installed implants with a minimum of six months of followup. The survival rate represents the persistence of implants, with no implant removal during follow-up, whereas the success rate represents criteria such as soft/hard tissue level, probing pocket depth, and bleeding on probing ${ }^{22}$. Also, the following variables were mentioned in some studies: 
- Healing time between the surgical and prosthetic phases

- Detailed surgical protocols/materials

\section{Information sources}

The information source were PubMed, Web of Science, and Scopus databases. The search was limited to Englishlanguage studies published before the end of August 2020. Hand searching was also conducted.

\section{Search strategy}

An electronic search was performed using the following keywords: Maxillary sinus AND (augmentation OR lift OR elevation) AND extraction, Maxillary sinus AND (augmentation OR lift OR elevation) AND osteotome sinus, Maxillary sinus AND (augmentation OR lift OR elevation) AND immediate implant placement.

\section{Study selection}

Two reviewers conducted the search using those keywords and then performed an initial screening of the titles and abstracts they found. Any disagreements between the reviewers were resolved by discussion. The reviewers then reviewed the full-text of the selected articles.

\section{Data items}

Data were extracted from the full-text of the articles and tabulated for comparison. The following variables were evaluated: technique of tooth extraction, extraction with/without elevating a flap, distance from the tooth apex to the sinus floor, instrument and technique for elevating the sinus floor, magnitude of the elevation of the sinus membrane, use or no use of graft materials and bone substitutes, implant height, method of wound closure in the coronal implant region, success rate and survival of implants, and the duration of followup.

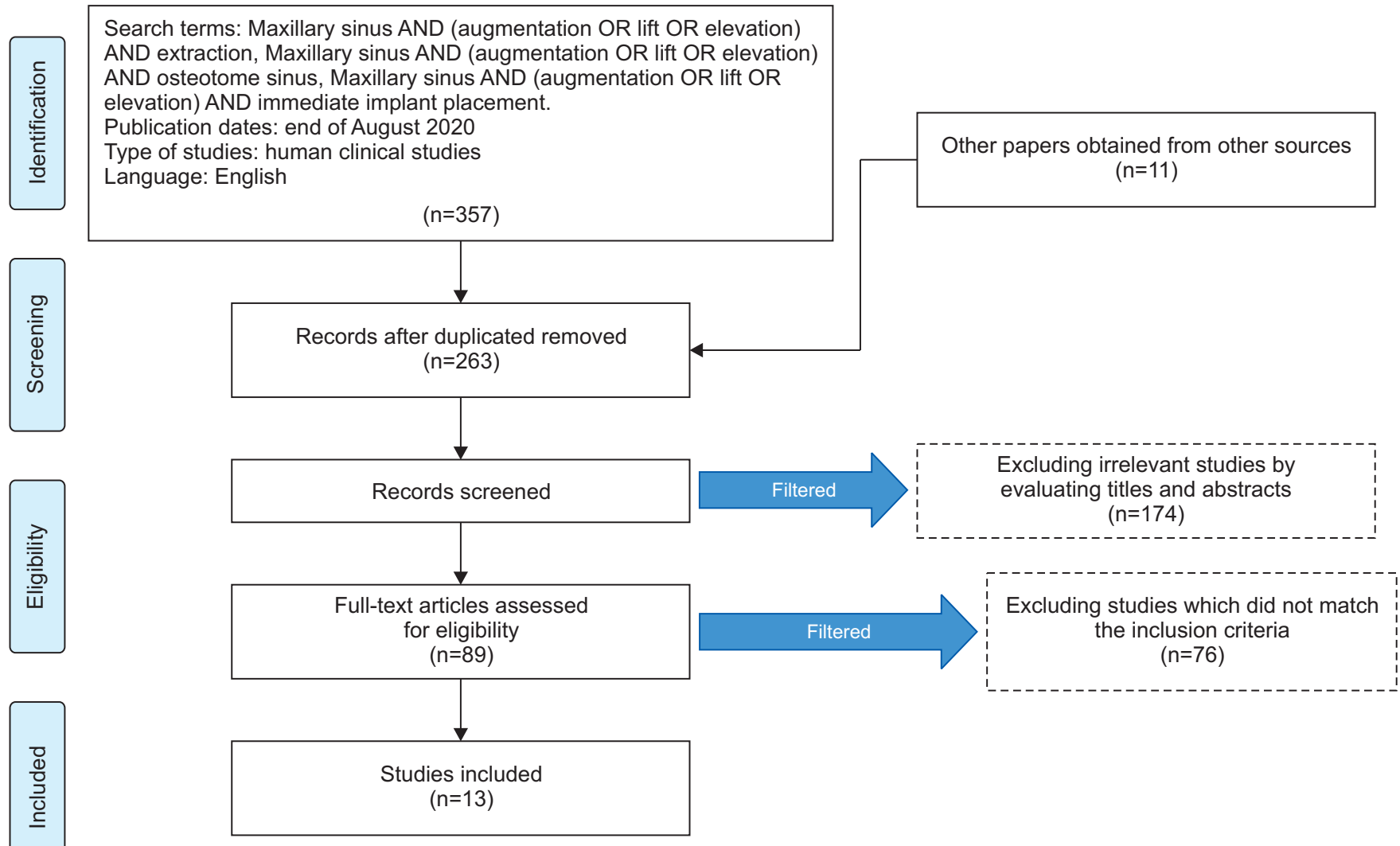

Fig. 1. Search strategy flowchart.

Mehdi Ekhlasmandkermani et al: Sinus floor elevation and simultaneous implant placement in fresh extraction sockets: a systematic review of clinical data. J Korean Assoc Oral Maxillofac Surg 2021 


\section{Data selection process}

Review and data extraction were performed according to the PRISMA flow diagrams. After the full-text of the selected articles were reviewed, data were extracted and tabulated. Disagreements between reviewers were resolved by consensus.

\section{Quality assessment}

The quality of the methodologies used in all the included studies was assessed. The criteria used were based on the ROBINS-I tool ${ }^{23}$ : bias due to confounding, bias in selecting participants, bias in classifying interventions, bias due to deviation from the intended intervention, bias due to missing data, bias in outcome measurements, and bias in selecting the reported results. The criteria used for the one randomized controlled trial were obtained from the Cochrane Center: selection bias, performance bias, detection bias, attrition bias, and reporting bias. The degree of bias was categorized as low risk, moderate risk, and serious risk. In cases with no data about a criterion, 'no information' is stated. Two individual investigators (L.K. and A.K.) performed the assessment and resolved conflicts through discussion.

\section{Results}

The initial search found 368 articles. After removing duplications and irrelevant studies, 89 studies were screened, which excluded 76 more articles because they did not perform sinus floor elevation through the socket of an extracted tooth or they did not place implants immediately after tooth extraction and sinus floor elevation. Therefore, 13 articles are described in this review.(Fig. 1) The results are reported in the form of questions and answers and presented in Tables 1 to 6 .

\section{What types of study designs were used by the authors?}

Of the 13 articles reviewed, six were retrospective case se$\operatorname{ries}^{12,24-28}$, three were case reports ${ }^{21,29,30}$, two were prospective cohorts in the form of case series ${ }^{31,32}$, one was a prospective case series $^{33}$, and one was a randomized controlled trial with one year of follow-up ${ }^{15}$.

\section{What demographic information was given for the patients enrolled?}

Of the 13 articles reviewed, 12 provided the number of patients evaluated ${ }^{12,15,21,24-27,29-33}$, and one did $\operatorname{not}^{28}$. A total of 245

Table 1. Properties of the reviewed studies

\begin{tabular}{|c|c|c|c|c|}
\hline Study & $\begin{array}{l}\text { Keywords related to sinus lift } \\
\text { through a fresh socket in the title }\end{array}$ & Study design & No. of patients & $\begin{array}{l}\text { No. of implants } \\
\text { with sinus lift }\end{array}$ \\
\hline Artzi et al. ${ }^{33}$ (2003) & $\begin{array}{l}\text { Internal sinus membrane elevation in } \\
\text { immediate post-extraction phase }\end{array}$ & Prospective case series & 10 & 10 \\
\hline Barone et al. ${ }^{25}$ (2008) & $\begin{array}{l}\text { Fresh extraction socket and osteotome } \\
\text { sinus floor elevation }\end{array}$ & Retrospective case series & 12 & 12 \\
\hline Kolhatkar et al. ${ }^{12}$ (2011) & Sinus floor elevation via extraction socket & Retrospective case series & 5 & 5 \\
\hline Bruschi et al. ${ }^{24}(2013)$ & $\begin{array}{l}\text { Localized management of sinus floor } \\
\text { technique in fresh socket }\end{array}$ & Retrospective case series & 53 & 68 \\
\hline $\begin{array}{l}\text { Taschieri and } \\
\text { Del Fabbro }{ }^{31}(2011)\end{array}$ & $\begin{array}{l}\text { Post-extraction osteotome sinus floor } \\
\text { elevation using PRGF }\end{array}$ & $\begin{array}{l}\text { Prospective single cohort } \\
\text { case series }\end{array}$ & 15 & 15 \\
\hline $\operatorname{McCrea}^{26}(2012)$ & $\begin{array}{l}\text { Trans-socket elevation/fracture/perforation } \\
\text { of sinus floor }\end{array}$ & Retrospective case series & 10 & 10 \\
\hline Mandelli et al. ${ }^{29}$ (2013) & $\begin{array}{l}\text { Sinus floor elevation and immediately } \\
\text { loaded post-extraction implant }\end{array}$ & Case report & 1 & 2 \\
\hline Crespi et al. ${ }^{27}(2013)$ & $\begin{array}{l}\text { Electrical mallet and osteotome sinus floor } \\
\text { elevation }\end{array}$ & Retrospective case series & 32 & 70 \\
\hline Ebenezer et al. ${ }^{28}$ (2015) & Indirect sinus lift in immediate implant & Retrospective case series & NM & NM \\
\hline Falcón $^{30}(2015)$ & $\begin{array}{l}\text { Post-extraction implant with internal sinus } \\
\text { floor elevation }\end{array}$ & Case report & 1 & 1 \\
\hline Chen et al. ${ }^{32}$ (2017) & $\begin{array}{l}\text { Transcrestal sinus floor augmentation in } \\
\text { fresh extraction socket }\end{array}$ & $\begin{array}{l}\text { Prospective cohort case } \\
\text { series }\end{array}$ & 37 & 37 \\
\hline Liu et al. ${ }^{15}(2019)$ & $\begin{array}{l}\text { Sinus floor elevation using the trans-alveolar } \\
\text { approach }\end{array}$ & $\begin{array}{l}\text { Randomized controlled } \\
\text { trial }\end{array}$ & 68 & 75 \\
\hline Sun et al. ${ }^{21}(2019)$ & NM & Case report & 1 & 1 \\
\hline
\end{tabular}

(PRGF: plasma rich in growth factors, NM: not mentioned)

Mehdi Ekhlasmandkermani et al: Sinus floor elevation and simultaneous implant placement in fresh extraction sockets: a systematic review of clinical data. J Korean Assoc Oral Maxillofac Surg 2021 
Table 2. Comparison of the reviewed studies regarding the target site, method of tooth extraction, flap/flapless technique, sinus lifting tool, and type of graft material

\begin{tabular}{|c|c|c|c|c|c|}
\hline Study & Target site & $\begin{array}{l}\text { Method of tooth } \\
\text { extraction }\end{array}$ & Flap/flapless & Sinus lifting tool & Graft material used \\
\hline $\begin{array}{l}\text { Artzi et al. }{ }^{33} \\
(2003)\end{array}$ & Molar & $\begin{array}{l}\text { Root hemisection, } \\
\text { elevator, forceps }\end{array}$ & Flap & Osteotome & $\begin{array}{l}\text { Synthetic beta-trical- } \\
\text { cium phosphate } \\
\text { xenograft }\end{array}$ \\
\hline $\begin{array}{l}\text { Barone et al. } \\
\text { (2008) }\end{array}$ & Premolar & $\mathrm{NM}$ & $\begin{array}{l}\text { Full thickness with } \\
\text { vertical release }\end{array}$ & Osteotome & $\begin{array}{l}\text { Mixture of collagen } \\
\text { gel and porcine } \\
\text { bone particles }\end{array}$ \\
\hline $\begin{array}{l}\text { Kolhatkar et al. }{ }^{12} \\
\text { (2011) }\end{array}$ & Premolar & $\begin{array}{l}\text { Periotome and } \\
\text { straight elevator }\end{array}$ & Flap & Osteotome & $\begin{array}{l}4 \text { allografts and } 1 \\
\text { xenograft }\end{array}$ \\
\hline $\begin{array}{l}\text { Bruschi et al. } .^{24} \\
(2013)\end{array}$ & Molar & Root hemisection & Flapless & $\begin{array}{l}\text { Bone expander and } \\
\text { mallet }\end{array}$ & Collagen sheet \\
\hline $\begin{array}{c}\text { Taschieri and Del } \\
\text { Fabbro }^{31}(2011)\end{array}$ & Premolar & $\begin{array}{l}\text { Elevator and } \\
\text { forceps }\end{array}$ & Full-thickness flap & $\begin{array}{l}\text { Piezosurgery and } \\
\text { osteotome }\end{array}$ & PRGF \\
\hline $\mathrm{McCrea}^{26}(2012)$ & Canine and premolar & Periotome & Full-thickness flap & Osteotome & None \\
\hline $\begin{array}{l}\text { Mandelli et al. }{ }^{29} \\
(2013)\end{array}$ & Premolar & $\mathrm{NM}$ & Flapless & Osteotome & Xenograft \\
\hline $\begin{array}{l}\text { Crespi et al. } \\
\text { (2013) }\end{array}$ & $\begin{array}{l}36 \text { molars and } 34 \\
\text { premolars }\end{array}$ & Molar hemisection & $\begin{array}{c}\text { Flapless or partial flap to } \\
\text { mobilize, if necessary }\end{array}$ & $\begin{array}{l}\text { Osteotome and } \\
\text { electrical mallet }\end{array}$ & NM \\
\hline $\begin{array}{l}\text { Ebenezer et al. }{ }^{28} \\
(2015)\end{array}$ & NM & $\mathrm{NM}$ & NM & Osteotome & NM \\
\hline Falcón $^{30}(2015)$ & Premolar & $\begin{array}{l}\text { Periotome and } \\
\text { elevator }\end{array}$ & Flapless & Osteotome & \\
\hline $\begin{array}{l}\text { Chen et al. }{ }^{32} \\
(2017)\end{array}$ & Molar & $\begin{array}{l}\text { Root hemisection } \\
\text { and intra-radicular } \\
\text { drilling }\end{array}$ & Flapless & $\begin{array}{l}\text { Specific membrane } \\
\text { separating instru- } \\
\text { ments and evaluation } \\
\text { with endoscope- } \\
\text { guided technique }\end{array}$ & $\begin{array}{l}\text { Gelatin sponge and } \\
\text { bone powder }\end{array}$ \\
\hline Liu et al. ${ }^{15}$ (2019) & Molar & NM & $\begin{array}{l}\text { Full thickness with } \\
\text { vertical release }\end{array}$ & Osteotome & None \\
\hline Sun et al. ${ }^{21}$ (2019) & Molar & $\mathrm{NM}$ & Flapless & $\mathrm{NM}$ & $\begin{array}{l}\text { Bio-Oss collagen } \\
\text { with PRF }\end{array}$ \\
\hline
\end{tabular}

(NM: not mentioned, PRGF: plasma rich in growth factors, PRF: platelet-rich fibrin)

Mehdi Ekhlasmandkermani et al: Sinus floor elevation and simultaneous implant placement in fresh extraction sockets: a systematic review of clinical data. J Korean Assoc Oral Maxillofac Surg 2021

patients were evaluated. Six studies reported the mean age of the patients ${ }^{15,24,27,31-33}$. Four studies mentioned only the age range of patients (youngest and oldest) ${ }^{12,25,26,28}$. Three studies evaluated only one patient and provided their exact age ${ }^{21,29,30}$. In the 13 reviewed studies, the youngest patient was 18 years, and the oldest was 74 years.

\section{How many implants were placed in extraction sockets using immediate implant placement and simultaneous sinus lifting?}

Overall, 306 implant fixtures were placed in 245 patients. The number of patients matched the number of inserted implants in eight studies ${ }^{12,21,25,26,30-33}$. In one study ${ }^{33}, 10$ implants were placed for 10 patients; out of which 8 were considered to be fresh socket implant placements simultaneous with sinus floor elevation, whereas in 2 cases, radiographs revealed that (in contrast to the researcher's belief at the time of surgery) the sinus membrane had not actually been elevated.
In four studies, the number of implants placed was greater than the number of patients ${ }^{15,24,27,29}$. In one of those studies ${ }^{29}$, despite the immediate placement of two implants in one patient, only one was accompanied by sinus lifting. Another study did not report the number of implants placed ${ }^{28}$. In one study $^{27}$, both premolar and molar sites underwent sinus lifting. Four studies ${ }^{15,24,32,33}$ evaluated only molar sites, and four studies $^{12,29-31}$ evaluated only premolar sites. In the randomized controlled trial, implant placement was performed for 33 patients immediately after tooth extraction and sinus lifting (test group), whereas the other 35 patients received implant placement and sinus lifting three months after tooth extraction (control group) $)^{15}$. Even though sinus floor elevation is more commonly performed in the premolar and molar regions, one study reported performing sinus floor elevation at the canine site, in addition to the premolar site ${ }^{26}$. 
Table 3. Comparison of the reviewed studies regarding the method of coronal coverage of the socket, pre- and postoperative complications, healing period, two-stage or one-stage surgery, and frequency of failure

\begin{tabular}{|c|c|c|c|c|c|}
\hline Study & $\begin{array}{l}\text { Method of coronal } \\
\text { coverage of the socket }\end{array}$ & $\begin{array}{l}\text { Pre- and postoperative } \\
\text { complications }\end{array}$ & $\begin{array}{l}\text { Healing } \\
\text { period }(\mathrm{mo})\end{array}$ & $\begin{array}{l}\text { Two-stage/one } \\
\text { stage }\end{array}$ & $\begin{array}{l}\text { Frequency of } \\
\text { failure }\end{array}$ \\
\hline $\begin{array}{l}\text { Artzi et al. }{ }^{33} \\
(2003)\end{array}$ & $\begin{array}{l}\text { Healing abutment and } \\
\text { coronal repositioning of } \\
\text { flap around its neck }\end{array}$ & $\begin{array}{l}\text { Epistaxis in } 2 \text { patients, micro- } \\
\text { perforation of the sinus } \\
\text { during surgery }\end{array}$ & 6 & One stage & None \\
\hline $\begin{array}{l}\text { Barone et al. } \\
\text { (2008) }\end{array}$ & $\begin{array}{l}\text { Release of periosteum and } \\
\text { suturing the flap around } \\
\text { the implant neck }\end{array}$ & Pain and swelling & 6 & 2 stage & $\begin{array}{l}1 \text { early failure } 6 \mathrm{wk} \\
\text { postoperatively }\end{array}$ \\
\hline $\begin{array}{l}\text { Kolhatkar } \\
\text { et al. }{ }^{12}(2011)\end{array}$ & $\begin{array}{l}2 \text { cases of healing } \\
\text { abutment, } 3 \text { cases of } \\
\text { suturing }\end{array}$ & None & $5-6$ & $\begin{array}{l}\text { One stage in } 2 \text { patients } \\
\text { and two-stage in } 3 \\
\text { patients }\end{array}$ & None \\
\hline $\begin{array}{l}\text { Bruschi et al. }{ }^{24} \\
\text { (2013) }\end{array}$ & Collagen sheet & $\begin{array}{l}\text { Pain, swelling, and epistaxis } \\
\text { (resolved after } 24 \text { to } 48 \mathrm{hr} \text { ) }\end{array}$ & 5 & Two stage & None \\
\hline $\begin{array}{l}\text { Taschieri and } \\
\text { Del Fabbro } \\
\text { (2011) }\end{array}$ & $\begin{array}{l}\text { Mucous membrane or } \\
\text { PRGF }\end{array}$ & None & $3-4$ & Two stage & None \\
\hline $\operatorname{McCrea}^{26}(2012)$ & $\begin{array}{l}\text { Coronal repositioning of } \\
\text { flap, healing abutment, } \\
\text { adhesive bridge }\end{array}$ & None & 6 & $\begin{array}{l}\text { One stage in } 2 \text { patients } \\
\text { and two-stage in } 8 \\
\text { patients }\end{array}$ & None \\
\hline $\begin{array}{l}\text { Mandelli et al. }{ }^{29} \\
\text { (2013) }\end{array}$ & $\begin{array}{l}\text { Temporary restoration, } \\
\text { leaving it out of occlusion }\end{array}$ & None & 5 & $\begin{array}{l}\text { One stage (temporary } \\
\text { restoration) }\end{array}$ & None \\
\hline $\begin{array}{l}\text { Crespi et al. } \\
(2013)\end{array}$ & $\begin{array}{l}\text { Suturing the collagen piece } \\
\text { and tissue covering the } \\
\text { implant }\end{array}$ & $\begin{array}{l}\text { Pain, swelling, and epistaxis } \\
\text { (resolved after } 24 \text { to } 48 \mathrm{hr} \text { ) }\end{array}$ & 5 & Two stage & $\begin{array}{l}1 \text { early failure } 1 \mathrm{mo} \\
\text { postoperatively }\end{array}$ \\
\hline $\begin{array}{l}\text { Ebenezer et al. } \\
\text { (2015) }\end{array}$ & $\begin{array}{l}\text { Immediate temporary } \\
\text { restoration and } \\
\text { immediate loading }\end{array}$ & NM & 4 & One stage & None \\
\hline Falcón ${ }^{30}$ (2015) & Suturing & None & 6 & Two stage & None \\
\hline $\begin{array}{l}\text { Chen et al. } \\
\text { (2017) }\end{array}$ & $\begin{array}{l}\text { Palatal slipping flap } \\
\text { or ultra-wide healing } \\
\text { abutment }\end{array}$ & $\begin{array}{l}1 \text { patient in Group 1: mild } \\
\text { rhinosinusitis and cough for } \\
3 \text { days } \\
1 \text { patient in Group 2: fatigue } \\
1 \text { patient in Group 3: fatigue } \\
\text { Other patients: toothache }\end{array}$ & 6 & One/two stage & None \\
\hline $\begin{array}{l}\text { Liu et al. } \\
\quad(2019)\end{array}$ & $\begin{array}{l}\text { Healing abutment and } \\
\text { suturing }\end{array}$ & $\begin{array}{l}\text { Perforation of the sinus during } \\
\text { surgery in two patients in } \\
\text { test group and one patient in } \\
\text { control group }\end{array}$ & 6 & One stage & None \\
\hline $\begin{array}{l}\text { Sun et al. } \\
\text { (2019) }\end{array}$ & $\begin{array}{l}\text { Healing abutment, loose } \\
\text { suturing with PRF } \\
\text { coverage }\end{array}$ & None & 6 & Two stage & None \\
\hline
\end{tabular}

(PRGF: plasma rich in growth factors, NM: not mentioned, PRF: platelet-rich fibrin)

Group 1: no contact of tooth apex with the sinus floor, Group 2: at least one tooth root was in contact with the sinus floor without perforating it, Group 3: at least one tooth root inside the sinus cavity.

Mehdi Ekhlasmandkermani et al: Sinus floor elevation and simultaneous implant placement in fresh extraction sockets: a systematic review of clinical data. J Korean Assoc Oral Maxillofac Surg 2021

\section{Did the existence of an infected tooth have any effect on the treatment outcomes?}

Six articles did not mention the probable existence of infection in the sockets ${ }^{15,21,25,28,30,31}$; four articles did not have any infected teeth in their patients ${ }^{15,21,24,29}$, and three studies excluded infected cases ${ }^{15,32,33}$. In three studies, prophylactic antibiotics were recommended ${ }^{12,15,27}$. In the two of them that included periapical radiolucencies or endodontal lesions, the survival rates were similar in infected and non-infected sites $^{12}$. Among the 70 dental implants installed in patients with a possible history of endo/periodontal disease, one fixture failed, but the exact etiology of that failure was not mentioned $^{27}$.

\section{Was flap surgery or the flapless technique adopted for tooth extraction and accessing the site of sinus lifting?}

Three studies reported using a Periotome for atraumatic tooth extraction ${ }^{12,27,30}$. Four studies did not mention the instruments used for tooth extraction ${ }^{21,25,28,29}$. Routine instruments available for tooth extraction, such as elevators and forceps, 
Table 4. Comparison of the reviewed studies regarding the follow-up period, method of measuring bone changes, baseline alveolar bone height, distance from the tooth apex to sinus floor, and magnitude of surgical sinus floor elevation

\begin{tabular}{|c|c|c|c|c|c|}
\hline Study & $\begin{array}{l}\text { Follow-up } \\
\text { period }\end{array}$ & $\begin{array}{l}\text { Method of measuring } \\
\text { bone changes }\end{array}$ & $\begin{array}{l}\text { Mean baseline alveolar } \\
\text { bone height }(\mathrm{mm})\end{array}$ & $\begin{array}{c}\text { Distance from } \\
\text { tooth apex to } \\
\text { sinus floor }(\mathrm{mm})\end{array}$ & $\begin{array}{l}\text { Magnitude of surgical } \\
\text { sinus floor elevation } \\
(\mathrm{mm})\end{array}$ \\
\hline Artzi et al..$^{33}(2003)$ & $2 \mathrm{yr}$ & PA with surgical template & $7.8(6-9)$ & NM & NM \\
\hline $\begin{array}{l}\text { Barone et al. } \\
\text { (2008) }\end{array}$ & $18 \mathrm{mo}$ & PA with occlusal stent & $7.8 \pm 1.9$ & Minimum of 2 & $\begin{array}{l}\text { Distance from sinus } \\
\text { floor to implant } \\
\text { apex: } 4.2 \pm 1.4\end{array}$ \\
\hline $\begin{array}{l}\text { Kolhatkar et al. }{ }^{12} \\
\text { (2011) }\end{array}$ & 6-12 mo & $\begin{array}{l}\text { PA or panoramic } \\
\text { radiography }\end{array}$ & NM & $<1$ or 2 & $\mathrm{NM}$ \\
\hline $\begin{array}{l}\text { Bruschi et al. }^{24} \\
(2013)\end{array}$ & $9.76 \pm 5.27 \mathrm{yr}$ & $\begin{array}{l}\text { PPA with occlusal template } \\
\text { and reference point }\end{array}$ & $6.02 \pm 0.75$ & NM & NM \\
\hline $\begin{array}{l}\text { Taschieri and Del } \\
\text { Fabbro }^{31}(2011)\end{array}$ & $\begin{array}{l}35.6 \mathrm{mo} \\
\quad(24-50 \mathrm{mo})\end{array}$ & PA & Minimum of 7 & NM & $2.9 \pm 0.8$ \\
\hline $\operatorname{McCrea}^{26}(2012)$ & $12-36 \mathrm{mo}$ & PA & NM & NM & NM \\
\hline $\begin{array}{l}\text { Mandelli et al. } \\
\text { (2013) }\end{array}$ & $4 \mathrm{yr}$ & PA & 5 & NM & NM \\
\hline Crespi et al. ${ }^{27}$ (2013) & $2 \mathrm{yr}$ & PPA with occlusal template & $6.55 \pm 1.34$ & NM & NM \\
\hline $\begin{array}{l}\text { Ebenezer et al. }{ }^{28} \\
(2015)\end{array}$ & NM & - & NM & NM & NM \\
\hline Falcón $^{30}$ (2015) & $12 \mathrm{mo}$ & $\mathrm{PA}$ & NM & 2 & NM \\
\hline Chen et al. ${ }^{32}$ (2017) & $12 \mathrm{mo}$ & $\mathrm{PA}$ and $\mathrm{CBCT}$ & $\begin{array}{l}\text { Distance from coronal inter- } \\
\text { radicular crest to sinus floor: } \\
\text { Group 1: } 6.60 \pm 1.01 \\
\text { Group 2: } 5.33 \pm 0.63 \\
\text { Group 3: } 4.54 \pm 0.64\end{array}$ & NM & NM \\
\hline Liu et al. ${ }^{15}$ (2019) & $12 \mathrm{mo}$ & $\mathrm{CBCT}$ & $\begin{array}{l}4.7 \pm 0.52 \text { (test group) } \\
4.9 \pm 0.63 \text { (control group) }\end{array}$ & NM & NM \\
\hline Sun et al. ${ }^{21}(2019)$ & None & PPA & 6 & 4 & NM \\
\hline
\end{tabular}

(PA: periapical radiography, NM: not mentioned, PPA: parallel periapical radiography, CBCT: cone-beam computed tomography)

Group 1: no contact of tooth apex with the sinus floor, Group 2: at least one tooth root was in contact with the sinus floor without perforating it, Group 3: at least one tooth root was inside the sinus cavity.

Values are presented as mean (range) or mean \pm standard deviation.

Mehdi Ekhlasmandkermani et al: Sinus floor elevation and simultaneous implant placement in fresh extraction sockets: a systematic review of clinical data. J Korean Assoc Oral Maxillofac Surg 2021

were used in the remaining studies. Among the 13 studies, one did not provide any information about the type of flap ${ }^{28}$, and 6 studies adopted the flapless technique $e^{21,24,27,29,30,32}$. In the six other studies, a full-thickness flap was elevated ${ }^{12,15,25,26,31,33}$.

\section{What instrument was used for sinus floor elevation?}

An osteotome with a hand mallet was used for sinus floor elevation in nine studies ${ }^{12,15,25,26,28,29,30,31,33}$. However, in one study, piezosurgery was performed first to reach the Schneiderian membrane, and then the sinus membrane was elevated using an osteotome ${ }^{31}$. In another study, an osteotome was used with an electrical mallet to control the force ${ }^{27}$. In one study, a bone expander was used with a mallet, which was believed to be similar to traditional osteotomes ${ }^{24}$. However, in two studies, rounded drills were used to reach the intact sinus membrane, and then various instruments were used to detach and elevate $\mathrm{it}^{15,32}$.

\section{Were graft materials or bone substitutes used for sinus floor elevation or to fill the gap between the implant and bony socket walls?}

Three of the 13 studies did not mention whether or not they used grafts or biomaterials $\mathrm{s}^{27,28,30}$. Of the remaining 10 articles, two studies reported placing no graft material beneath the sinus membrane ${ }^{15,26}$. One study used plasma rich in growth factors (PRGF) as an autograft for sinus membrane elevation ${ }^{31}$. One study placed a collagen sheet beneath the sinus membrane ${ }^{24}$, and two studies used collagen compounds along with a xenograft ${ }^{25,32}$. One study used only a xenograft ${ }^{29}$. Another study used a xenograft or synthetic beta-tricalcium phosphates $^{33}$, whereas another article reported using a xenograft in some cases and an allograft in others ${ }^{12}$. Only one article placed a xenograft with platelet rich fibrin (PRF) in the space between the implant and the socket walls ${ }^{21}$. 
Table 5. Comparison of the reviewed studies regarding the implant height and bone height/bone gain and bone loss after the healing period and during the follow-up period

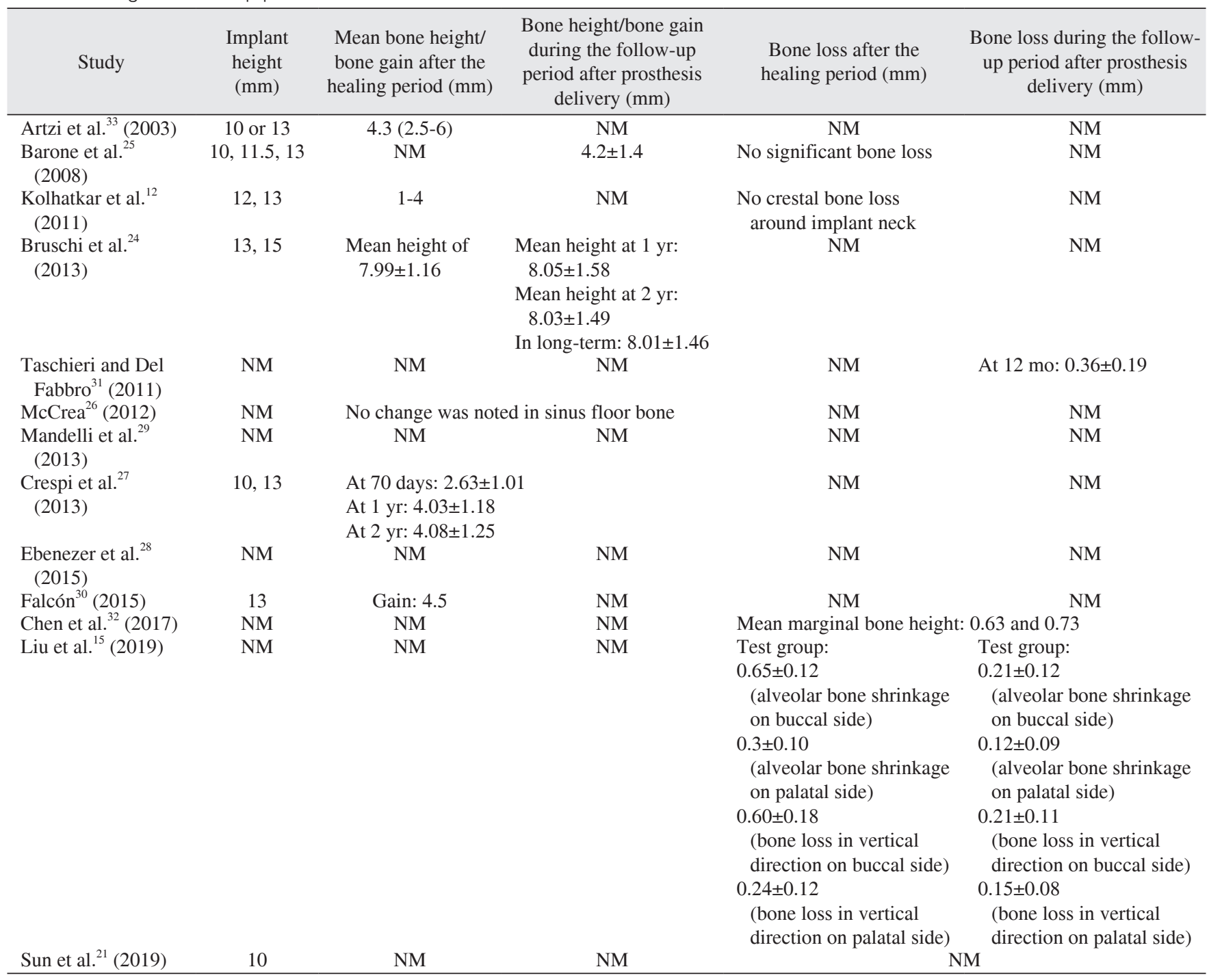

(NM: not mentioned)

Values are presented as mean (range) or mean \pm standard deviation.

Mehdi Ekhlasmandkermani et al: Sinus floor elevation and simultaneous implant placement in fresh extraction sockets: a systematic review of clinical data. J Korean Assoc Oral Maxillofac Surg 2021

\section{What was the method of measuring bone and its subsequent changes?}

Five of the 13 articles used periapical radiography $y^{21,26,29,30,31}$, and four used periapical radiography along with an occlusal or surgical template to increase the accuracy of measurements ${ }^{24,25,27,33}$. One study used periapical or panoramic radiography ${ }^{12}$. One study used cone-beam computed tomography $(\mathrm{CBCT})^{15}$, and another one used both CBCT and periapical radiography ${ }^{32}$. In one study, one patient had a panoramic radiograph in his records, but the type of radiography used for the other patients was not specified ${ }^{28}$.

\section{What was the alveolar bone height and distance from the tooth apex to the sinus floor at baseline?}

Four studies did not specify the primary bone height at baseline $e^{12,26,28,30}$. Table 4 shows the mean primary bone height at baseline in the other studies.

\section{What was the magnitude of sinus floor elevation and what implant height was used?}

Three studies mentioned the magnitude of sinus floor elevation $^{15,25,31}$, of which two measured it directly and reported that it was approximately $2.9 \mathrm{~mm}^{25}, 3.6 \mathrm{~mm}$ (case group), 
Table 6. Comparison of the reviewed studies regarding the implant survival rate and their conclusions

\begin{tabular}{|c|c|c|}
\hline Study & $\begin{array}{l}\text { Survival/ } \\
\text { Success rate }\end{array}$ & Conclusion \\
\hline Artzi et al. ${ }^{33}(2003)$ & $\begin{array}{l}\text { Survival: } \\
100 \%\end{array}$ & $\begin{array}{l}\text { A combination of these two techniques as one single procedure yields results comparable to each } \\
\text { of the techniques alone in the short-term, decreases the treatment time and cost, and enhances the } \\
\text { prosthetic rehabilitation of the posterior maxilla. }\end{array}$ \\
\hline Barone et al. ${ }^{25}(2008)$ & $\begin{array}{c}\text { Success: } \\
91.7 \%\end{array}$ & This technique yields predictable results and enables horizontal and vertical expansion. \\
\hline Kolhatkar et al. ${ }^{12}(2011)$ & $\begin{array}{l}\text { Survival: } \\
100 \%\end{array}$ & $\begin{array}{l}\text { Authors provided a decision-making flowchart for clinicians wanting to use the combined technique. } \\
\text { This technique shortens the treatment time and is flexible for placement of longer implants close } \\
\text { to the sinus. }\end{array}$ \\
\hline Bruschi et al. ${ }^{24}(2013)$ & $\begin{array}{l}\text { Survival: } \\
100 \%\end{array}$ & $\begin{array}{l}\text { This technique enables horizontal and vertical expansion and allows for placement of implants with } \\
\text { a larger diameter in the maxillary molar area with } 100 \% \text { successful osseointegration that can well } \\
\text { tolerate occlusal loads. }\end{array}$ \\
\hline $\begin{array}{l}\text { Taschieri and Del } \\
\text { Fabbro }^{31}(2011)\end{array}$ & $\begin{array}{l}\text { Success: } \\
100 \%\end{array}$ & $\begin{array}{l}\text { This technique can enable safe and efficient sinus floor elevation along with immediate implant } \\
\text { placement. Use of PRGF in this technique can stimulate bone regeneration and soft tissue healing } \\
\text { and enhance treatment acceptance by patients. }\end{array}$ \\
\hline $\operatorname{McCrea}^{26}(2012)$ & $\begin{array}{l}\text { Success: } \\
100 \%\end{array}$ & $\begin{array}{l}\text { Same socket/osteotomies can be used as a conduit for modified sinus floor penetration/elevation } \\
\text { without the use of an autograft, allograft, or xenograft. This technique significantly shortens the } \\
\text { treatment time and decreases the need for further surgical interventions. }\end{array}$ \\
\hline Mandelli et al. ${ }^{29}(2013)$ & $\begin{array}{l}\text { Success and } \\
\text { survival: } \\
100 \%\end{array}$ & $\begin{array}{l}\text { Sinus lifting simultaneous with fresh socket implant placement decreases the treatment time. The } \\
\text { success of this procedure depends on the primary stability of the implant. Splinting two adjacent } \\
\text { implants results in predictable osseointegration. }\end{array}$ \\
\hline Crespi et al. ${ }^{27}(2013)$ & $\begin{array}{r}\text { Survival: } \\
98.57 \%\end{array}$ & $\begin{array}{l}\text { Use of an electrical mallet for bone condensation is fast, accurate, and cost-effective, and it seems to } \\
\text { be a suitable instrument for preparing the upper parts of the socket for simultaneous sinus lifting } \\
\text { and implant placement. }\end{array}$ \\
\hline Ebenezer et al. ${ }^{28}(2015)$ & NM & $\begin{array}{l}\text { Indirect sinus lifting with the crestal approach using an osteotome is simple, non-invasive, and fast. } \\
\text { The apical bone pushed into the sinus can serve as a bone graft and tent for the sinus membrane. } \\
\text { Also, the bone at the sinus floor can increase the primary stability of the implant. }\end{array}$ \\
\hline Falcón ${ }^{30}(2015)$ & NM & $\begin{array}{l}\text { The flapless technique is less invasive and further decreases the treatment time and postoperative } \\
\text { patient discomfort. }\end{array}$ \\
\hline Chen et al. ${ }^{32}(2017)$ & $\begin{array}{l}\text { Survival: } \\
100 \%\end{array}$ & $\begin{array}{l}\text { The combination of these two techniques yields predictable results, especially when inter-radicular } \\
\text { bone is used. The relationship between the molar root and sinus can have an inverse correlation } \\
\text { with the radicular bone height and a direct correlation with the sinus floor thickness. Normally, } \\
\text { the sinus membrane thickness increases postoperatively due to the formation of a blood clot and } \\
\text { the infiltration of goblet cells, which returns to normal after the healing period. Root infection is } \\
\text { an odontogenic factor responsible for increased membrane thickness. Eliminating the infected root } \\
\text { allows the membrane to become thin again. }\end{array}$ \\
\hline Liu et al. ${ }^{15}$ (2019) & $\begin{array}{l}\text { Survival: } \\
100 \%\end{array}$ & $\begin{array}{l}\text { Immediate implant placement combined with maxillary sinus floor elevation using the trans- } \\
\text { alveolar approach and non-submerged healing is feasible for the maxillary molar area, and the } \\
\text { clinical effect is satisfactory. }\end{array}$ \\
\hline Sun et al. ${ }^{21}(2019)$ & NM & $\begin{array}{l}\text { Flapless, immediate implant placement into a fresh molar socket with PRF is a feasible procedure. } \\
\text { PRF promotes bone and soft tissue regeneration and has anti-inflammatory properties. In addition, } \\
\text { the procedure involves a minimally invasive technique that reduces surgical complexity. }\end{array}$ \\
\hline
\end{tabular}

(PRGF: plasma rich in growth factors, NM: not mentioned, PRF: platelet-rich fibrin)

Mehdi Ekhlasmandkermani et al: Sinus floor elevation and simultaneous implant placement in fresh extraction sockets: a systematic review of clinical data. J Korean Assoc Oral Maxillofac Surg 2021

and $3.4 \mathrm{~mm}$ (control group) $)^{15}$. The other study ${ }^{31}$ estimated the magnitude of sinus floor elevation to be $4.2 \mathrm{~mm}$ by measuring the approximate distance from the implant apex to the sinus floor. Seven studies mentioned the implant height ${ }^{12,21,24,25,27,30,33}$. The most common implant height in all the reviewed studies was $13 \mathrm{~mm}$; the shortest implant was 10 $\mathrm{mm}$, and the longest was $15 \mathrm{~mm}$.

\section{What were the changes in bone height, both bone gain and bone loss, during the healing phase and follow-up periods?}

Six studies evaluated the effect of using or not using bone grafts on the amount of bone gain, and their results can be categorized into two groups ${ }^{12,24,25,31-33}$. The first group, which reported bone gain, included the following studies. A study that used collagen sponges alone ${ }^{24}$ and reported that the mean bone height at baseline (time of surgery) was $6.02 \pm 0.75 \mathrm{~mm}$, which increased to $8.05 \pm 1.58 \mathrm{~mm}$ at the one-year followup and remained constant at $8.01 \pm 1.46 \mathrm{~mm}$ thereafter. An- 
other study used a combination of collagen and xenograft bone powder ${ }^{25}$ and reported $4.2 \pm 1.4 \mathrm{~mm}$ of bone gain at the 18-month follow-up. One study used an allograft in 4 out of 5 patients, and the remaining patient received a xenograft. The amount of bone gain was reported to be 1-4 $\mathrm{mm}$ at the 6- and 12-month follow-ups ${ }^{12}$. Another study used xenograft or beta tricalcium phosphate, and postoperative radiographs showed 2.5-6 $\mathrm{mm}$ of bone gain, with a mean value of $4.3 \mathrm{~mm}$. Those patients showed optimal clinical stability and support of the prosthesis at their 2-year follow-up visits ${ }^{33}$.

The second group evaluated crestal bone loss. In 2008, Barone et $a .^{25}$ reported no significant bone resorption after the placement of 12 implants despite elevating a full-thickness flap. Artzi et al. ${ }^{33}$ performed flap surgery for the placement of 12 implants in 2003 and reported no crestal bone resorption around the implant neck. In 2017, Chen et al. ${ }^{32}$ used the flapless technique to place 37 implants and comprehensively evaluated marginal bone resorption at the 6- and 12-month follow-ups. The mean crestal bone loss was 0.63 and 0.73 $\mathrm{mm}$ at the 6- and 12-month follow-ups, respectively ${ }^{32}$. Taschieri and Del Fabbro ${ }^{31}$ evaluated crestal bone loss in 2011 and reported that the peri-implant bone loss averaged $0.36 \pm 0.19$ $\mathrm{mm}$ at the 12-month follow-up.

\section{Is there a suggested treatment plan for covering the coronal area of the socket following implant placement?}

In two studies, the presented cases immediately received a temporary prosthesis that sealed the socket opening ${ }^{28,29}$. Two other studies used collagen sponges as appropriate closures for the socket opening ${ }^{27,32}$. One study comprehensively discussed the coronal seal ${ }^{26}$ and used three methods for this purpose: (A) providing mucosal coverage by elevating a flap, (B) using an adhesive bridge, and (C) placing a healing abutment. In some cases, a combination of those techniques (A and $\mathrm{B}$ or $\mathrm{B}$ and $\mathrm{C}$ ) was used. In the study that used $\mathrm{PRGF}^{31}$, all implants were semi-submerged in mucosal tissue with/ without PRGF. In another article, the wound was covered with a PRF membrane and loose sutures ${ }^{21}$. In the remaining cases $^{12,15,25,26,30,32,33}$, the socket was partially sealed by suturing or the use of healing abutments. Of the studies that used sutures, one study reported using the palatal slipping flap technique for coronal coverage of the socket in some cases ${ }^{32}$. Another study released the flap and sutured it at the coronal part of the socket and then fabricated a temporary fixed prosthesis to prevent trauma to the surgical site; after 2 to 3 weeks, it was replaced with a removable prosthesis ${ }^{25}$.

\section{Was there any complication during or after the surgical procedure?}

Seven studies did not report any peri- or postoperative complications $^{12,21,26,28-31}$. One study divided patients into three groups according to the distance from the apex to the sinus floor ${ }^{32}$ and reported that one patient in group 1 developed mild rhinosinusitis and cough in the first three days postoperatively, one patient from group 2 and one patient from group 3 developed fatigue, and other patients reported dental pain. Two studies reported sinus membrane perforation during the surgical procedure in two (test group) and one (control group) ${ }^{15}$ and three $e^{33}$ patients. Nasal bleeding was also reported in two patients in the same study ${ }^{33}$. Two other studies reported pain and swelling as well as nasal bleeding postoperatively ${ }^{24,27}$, but they also reported that those symptoms resolved within 24 to 48 hours without significant complication. Another study reported only pain and swelling postoperatively ${ }^{25}$.

\section{How long was the healing period and prosthetic phase until the delivery of final restoration?}

Nine studies did not attach a temporary prosthesis to the implant platform before delivery of the final restora$\operatorname{tion}^{12,15,21,25,26,30-33}$. Two studies by a single group of research$\mathrm{ers}^{25,27}$ fabricated a temporary prosthesis 70 days after implant placement and then delivered the final prosthesis 2 to 3 months after that. In two other studies, the treatment was accomplished by immediate delivery of a fixed prosthesis temporarily connected to the implant ${ }^{28,29}$. In one of them, the crown was out of the occlusion ${ }^{29}$ and in the other, it was loaded immediately ${ }^{28}$. In terms of time lapse until restoration, one study reported 3 to 4 months ${ }^{31}$, another indicated 4 months ${ }^{28}$, three studies mentioned 5 months ${ }^{24,28,29}$, seven studies ${ }^{15,21,25,26,30,32,33}$ reported 6 months, and one study ${ }^{12}$ reported 5 to 6 months between the surgical procedure and final restoration.

\section{How many implants failed during the healing or follow-up period and what was the survival rate or success rate of implants during the follow-up period?}

In 10 articles, all the implants were stable during the healing and follow-up periods with no failures ${ }^{12,15,21,24,26,29-33}$. One study did not specify the number of patients or implants and only mentioned the successful management of the $\operatorname{cases}^{28}$. 
Failures were reported in two studies ${ }^{25,27}$, which were both case-series. One of them reported the failure of 1 out of 12 implants due to infection and abscess ${ }^{25}$ that occurred 6 weeks after the surgical procedure and was categorized as an early failure. In the other study ${ }^{27}, 1$ out of 70 implants failed one month after placement, and it was successfully replaced with another implant after 6 months. Thus, those two studies reported a $91.7 \%$ success rate ${ }^{25}$ and $98.57 \%$ survival rate $^{27}$ for the implants. In other studies, both those rates were $100 \%^{12,15,21,24,26,29,31-33}$ or no information about the survival or success rate was given ${ }^{28,30}$.

16. What was the duration of follow-up and the frequency of recall sessions after the primary healing period, and what was the frequency of repeated radiographs until manuscript submission?

Two studies reported regular recall sessions from the time of surgery until delivery of the final prosthesis ${ }^{12,25}$. In one of them ${ }^{25}$, the postoperative patients were followed up monthly for up to 6 months for prophylaxis. After delivery of the final prosthesis, all patients showed up for regular recall sessions after 2 to 4 months. The duration of follow-up was 18 months, and radiographic examinations were carried out at 6 and 18 months postoperatively. In the second study ${ }^{12}$, the recall sessions were scheduled at 2 weeks, 2 months, and 5 months during the healing period. The final prosthesis was delivered 6 to 14 months postoperatively. After that, all patients were followed up at 6 and 12 months. One study mentioned only the time of delivery of the final prosthesis at 4 months postoperatively ${ }^{28}$ and did not mention the tim- ing of the other follow-up sessions. Three studies followed up with patients at 12 months ${ }^{15,30,32}$ without mentioning the frequency of recall sessions during that time period. Two other studies reported a final follow-up visit with patients at 2 years ${ }^{27,33}$ but did not mention recall sessions during that period. In two studies conducted by a single group of research$\mathrm{ers}^{24,27}$, the recall sessions and radiographic examinations were scheduled at 70 days postoperatively. In one of them ${ }^{27}$, follow-up and radiographic examinations were scheduled 1 and 2 years later, but in the second study ${ }^{24}$, the follow-up sessions were scheduled annually after prosthesis delivery for a mean of 9.76 \pm 5.27 years (range, 4-17 years). In one study, radiography was performed at the time of prosthesis delivery. Of the 10 patients in that study, 1 was followed up at 12 months, 2 were followed up at 18 months, 4 were followed up at 24 months, 1 was followed up at 30 months, and 2 were followed up at 36 months ${ }^{26}$. One study reported 4 years of follow-up but did not mention the time interval between recall sessions ${ }^{29}$. In another study, the prosthesis was delivered 4 months postoperatively, and recall sessions were then scheduled 6 and 12 months after that and continued annually, with a mean follow-up time of 35.6 months (range, 24-50 months $)^{31}$. In only one study, there were no recall sessions after definitive restoration delivery ${ }^{21}$.

\section{Quality assessment}

Our assessment of the risk of bias is presented in Fig. 2. Most of the 11 non-randomized studies reported a low risk of bias in confounding. The three highest values with a moderate risk of bias were for deviation from the intended inter-

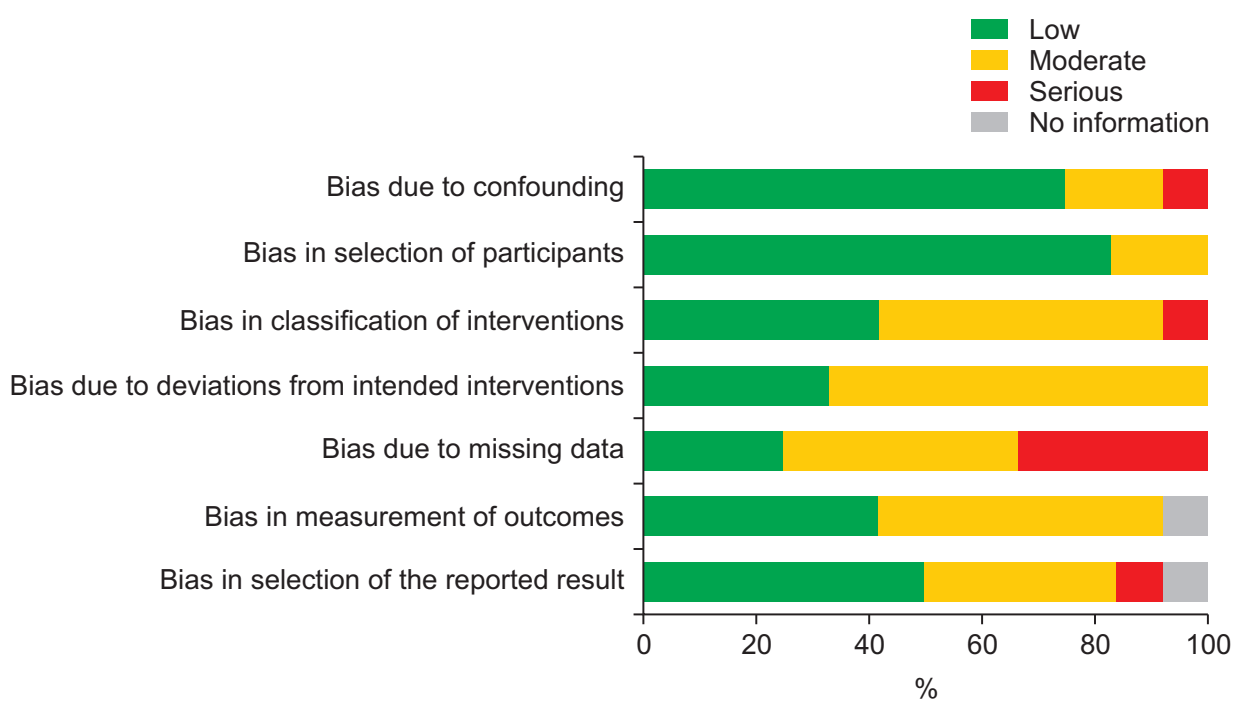

Fig. 2. Risk of bias assessment in nonrandomized clinical studies. Mehdi Ekhlasmandkermani et al: Sinus floor elevation and simultaneous implant placement in fresh extraction sockets: a systematic review of clinical data. J Korean Assoc Oral Maxillofac Surg 2021 
vention $(67 \%)$, classification of intervention and outcome measurements $(50 \%)$, and missing data $(42 \%)$. For the only randomized controlled trial, blinding of the outcome assessment was evaluated as high risk. Besides randomization bias, which presented a low risk, other criteria were reported to carry a moderate risk of bias. Considering all the values related to the risk of bias assessment, the studies included were categorized as being of moderate quality.

\section{Discussion}

Sinus floor elevation with a crestal approach can be performed through the site of a healed extraction socket in an edentulous posterior maxilla (Summers' technique) or through a fresh extraction socket as explained by Fugazzotto ${ }^{34}$ in 1999. Immediate implant placement in a fresh extraction socket at the same time as sinus floor elevation through that socket has been attempted only since $2000^{33}$.

This relatively new approach has combined tooth extraction, socket healing, sinus floor elevation to increase bone height, and implant osseointegration into a single procedure ${ }^{15}$. Analyzing all the documented data collected in different studies on this topic can enhance our understanding of this technique.

The characteristics required for the success of immediate implant placement in the clinical setting include (I) atraumatic tooth extraction, (II) sterile and minimally invasive surgical procedures, and (III) adequate primary stability of the implant ${ }^{35,36}$. Of those three parameters, atraumatic tooth extraction is an important starting point because preservation of the bony socket walls is critical for achieving maximum bone formation around an implant placed in a fresh extraction socket. What matters most during tooth extraction is the precision needed to prevent traumatization of the socket.

Our aim in this systematic review was to review different techniques and determine their advantages and disadvantageous for immediate implant placement and sinus floor elevation through a fresh extraction socket in the posterior maxilla.

\section{Flap versus flapless approach}

The elevation of a full-thickness flap can be associated with a higher risk of crestal bone resorption ${ }^{37}$. On the other hand, flapless surgery can cause errors in correct implant placement due to inadequate visualization of the surgical site $^{38}$. Three sources, the PDL, bone marrow, and external periosteum, provide blood supply to the buccal bone around the teeth ${ }^{39,40}$. Following tooth extraction, the blood supply provided by the PDL is no longer available. A thin buccal plate is mainly composed of cortical bone, so in those cases, the periosteum would be the only source of blood supply to the buccal bone plate ${ }^{41}$. Therefore, elevating a flap can impair the blood supply to the buccal bone plate provided by the periosteum ${ }^{37}$, which can aggravate resorption of the buccal bone plate following tooth extraction ${ }^{41}$. Faster soft-tissue healing, decreased perioperative hemorrhaging, shorter surgical time, and less patient discomfort postoperatively are other advantages of flapless surgery. On the other hand, the surgical procedure in flapless surgery is performed blindly, which can lead to fenestration of the osteotomy site and implant mispositioning ${ }^{42,43}$. A meta-analysis conducted in 2014 compared the flap and flapless surgical procedures for implant placement in healed extraction sockets and indicated that the risk of implant failure was higher in flapless surgery in most of the reviewed studies ${ }^{38}$. It should be noted that in immediate implant placement, the coronal part of the socket allows adequate visualization of implant placement in the alveolar housing, and the soft and hard tissue conditions are favorable, so there would be no need to elevate a flap unless the surgeon wanted to reposition the flap coronally to cover the coronal part of the socket. In that case, there would be no need to elevate a full-thickness flap because a partial-thickness flap would serve that purpose. Therefore, it seems that crestal bone resorption following flap elevation in immediate implant placement is a more important issue than mispositioning of the implant.

In this review, an equal number of studies used the flap

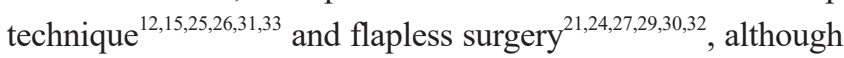
more implants were placed with the flapless technique (173 implants) than via flap surgery (125 implants). Implant failure occurred with both techniques.

The correlation between crestal bone resorption and flap/ flapless surgery was also previously reviewed ${ }^{44}$. Those results showed that the mean magnitude of resorption was less than $1 \mathrm{~mm}$ or not significant $\mathrm{t}^{25,31-33}$. According to the implant success criteria, that amount of resorption is within the clinically acceptable range ${ }^{45}$. Moreover, a study conducted in 2017 found no significant difference in ridge resorption following immediate implant placement with the flap or flapless technique $^{41}$, which is in agreement with our findings.

\section{Sinus lifting techniques}

Since the introduction of the closed sinus lift technique 
with the crestal approach ${ }^{8}$, osteotomes have been conventionally used for this purpose. In 2005, a meta-analysis reported $95.7 \%$ and $96 \%$ success/survival rates at 24 and 36 months, respectively, following implant placement with the osteotome technique, and those rates were similar to those with conventional implant placement in a partially edentulous posterior maxilla $^{46}$. However, another study reported that the risk of membrane perforation posed by techniques such as the hydraulic sinus lift procedure at the crestal site was less than that with the conventional use of osteotomes?

Osteotome use can be accompanied by some complications. The mallet strokes used in the original crestal technique to create a "green stick" fracture and access the sinus membrane can cause discomfort and complications for patients ${ }^{47}$. However, osteotomes are still popular for crestal sinus lifting, such that in 10 out of the 13 studies reviewed here, an osteotome was the main instrument used for sinus floor elevation ${ }^{12,15,25-31,33}$. One study used an electrical mallet instead of a hand mallet because the authors believed that it enabled better control of the force applied to the osteotome and decreased postoperative patient discomfort by decreasing trauma to the bone and craniofacial structures ${ }^{27}$. The authors in one of the reviewed studies used specific separating instruments to elevate the sinus membrane and reported no sign of membrane perforation during surgery ${ }^{32}$. Only two studies mentioned perforation of the sinus membrane during surgery, but they also reported that it caused no implant failure during one-year ${ }^{15}$ and two-years of follow-up ${ }^{12}$. According to the available evidence, particularly a systematic review conducted in 2016, membrane perforation is the most common complication of sinus lifting, but no significant association has been found between the implant success rate and sinus membrane perforation ${ }^{48}$. Therefore, use of osteotomes is still the gold standard for the crestal approach.

In 1994, Summers ${ }^{8}$ suggested that a minimum of 5-6 mm of residual bone height is required to ensure primary stability of the implant. Measuring the primary bone height beneath the sinus floor is easier in a healed edentulous ridge than in a fresh extraction socket. The references used for such measurements might be different in fresh extraction sockets, which is one of the limitations to accurately measuring bone changes when performing sinus lifting through an extraction socket. Our data indicate that the minimum residual bone height relative to the inter-radicular crest (as reference) was $4.54 \pm 0.64 \mathrm{~mm}^{32}$. That value was $5 \mathrm{~mm}$ when the interproximal crest served as the reference ${ }^{29}$. Neither of those studies reported any implant failures. A systematic review in 2014 reported that a bone height less than $4 \mathrm{~mm}$ was associated with a lower success rate with the osteotome technique ${ }^{10}$. In contrast, a meta-analysis conducted in 2018 showed that the survival rate of implants placed in residual bone with $\leq 4$ $\mathrm{mm}$ of height was only slightly lower than that of implants placed in residual bone with $>4 \mathrm{~mm}$ of height $\mathrm{t}^{49}$. It seems that the amount of residual bone between the apex and the sinus floor and the amount of inter-radicular bone are more important to primary implant stability and the failure rate than the proximal bone level. Implant failure was reported in only two cases in the articles reviewed here. In one of the failed cases $^{25}$, the minimum bone thickness between the tooth apex and sinus floor was only $2 \mathrm{~mm}$ but was deemed adequate for primary stability of the implant, and the reason for failure after six weeks was infection and abscess, not inadequate primary stability. The other study that reported a failed case mentioned nothing about the distance from the tooth apex to the sinus floor, nor did it specify the reason for implant failure $^{27}$. However, it should be noted that in our study, similar to the meta-analysis conducted in $2018^{49}$, measurements were made on periapical or panoramic radiographs; only one study used $\mathrm{CBCT}$ with periapical radiography for that purpose ${ }^{32}$, which could limit the accuracy of the reviewed results.

For vertical and horizontal bone expansion, osteotomes ${ }^{25}$, bone expanders and mallets ${ }^{24}$, and expander screws ${ }^{50}$ were applied in premolar, molar, and both premolar and molar sites, respectively. The overall results with these methods showed survival and success rates comparable to those of standard surgery, ranging from $95 \%$ to $100 \%$, indicating that the choice of devices does not have a notable effect on the outcomes. Also, a recent study showed that transcrestal sinus floor elevation has no negative effect on the long-term survival rate of implants ${ }^{51}$.

\section{Graft materials}

The application of graft materials below the sinus membrane following its elevation is a challenging topic in sinus lifting with the crestal approach ${ }^{52}$. Some of the studies reviewed here evaluated how using or not using graft materials affected bone gain, bone loss, and the survival and success rates of implants ${ }^{48,53}$.

Two reasons have been suggested for new bone formation in a sinus cavity that has undergone sinus floor elevation using an osteotome: osteogenic activity after a mini-fracture of bone at the sinus floor and the role of mesenchymal cells present in the Schneiderian membrane ${ }^{54}$. Therefore, maintain- 
ing the sinus membrane in an elevated position, either with graft materials and bone substitutes or by the implant apex, can trigger new bone formation beneath the membrane so long as the blood clot is preserved ${ }^{11}$. A randomized clinical trial in 2013 evaluated the survival rates of implants with and without grafting and reported similar residual bone heights and survival rates of $95.2 \%$ and $95 \%$, respectively ${ }^{54}$. The marginal bone loss did not differ significantly between the two groups after 3 years, but the amount of bone gain in the graft group was significantly higher than that in the no graft group after 6 months. However, bone gain significantly decreased after 3 years in the graft group, whereas it continued to grow slowly in no-graft group. At the 3-year follow-up, the final volume of bone within the sinus was equal in the two groups (around $3 \mathrm{~mm})^{54}$. Nonetheless, a meta-analysis conducted in $2018^{49}$ reported that the results of studies about bone gain supported the use of graft materials beneath the sinus membrane. In this meta-analysis ${ }^{49}$, the amount of marginal bone loss in the bone graft group was slightly higher than that in the no-graft group, but that difference was not significant. However, the amount of bone gain did differ significantly between the groups. No significant difference was found in the implant survival rate with the use and non-use of a bone graft beneath the sinus membrane, which was in agreement with the findings of a meta-analysis conducted in $2017^{11}$. In this review, we evaluated studies that performed sinus lifting with and without the placement of bone grafts, but more studies used an autogenous bone graft ${ }^{29}$, bone substitute $\mathrm{e}^{12,21,25,29,32,33}$, or collagen sponges ${ }^{24}$ than did not place any biomaterial beneath the sinus membrane ${ }^{26}$. All studies that reported bone gain used some sort of collagen material or bone substitute beneath the sinus membrane. However, it is noteworthy that in the only study that used PRGF to keep the sinus membrane elevated, the elevation averaged $2.9 \pm 0.8 \mathrm{~mm}$, but the amount of bone gain was not mentioned at the time of prosthesis delivery or the follow-up sessions ${ }^{31}$. Therefore, our results are in line with the findings of a recent meta-analysis ${ }^{49}$ that showed that greater increase in bone height can be expected when using bone grafts.

\section{Conclusion}

Sinus floor elevation through a fresh extraction socket and simultaneous immediate implant placement seems to be a proper treatment choice and has noticeably high success. Nevertheless, case selection and the capability of the clinician are important factors.

\section{Clinical recommendations}

Controlled clinical trials are seriously lacking on this topic and are therefore recommended. Calculating important data, including initial bone height, amount of sinus lifting, clinical and radiographic criteria pertaining to the success of implants, follow-up to the prosthetic and loading phases, and split mouth designs, are suggested for further studies. Also, some important factors such as patient-oriented outcomes, digital workflow, and presence of sinus septa in the apical socket should be emphasized in further research.

\section{ORCID}

Mehdi Ekhlasmandkermani, https://orcid.org/0000-00020456-1740

Reza Amid, https://orcid.org/0000-0002-8053-3928

Mahdi Kadkhodazadeh, https://orcid.org/0000-0002-61312791

Farhad Hajizadeh, https://orcid.org/0000-0003-0608-6100

Pooria Fallah Abed, https://orcid.org/0000-0003-02197559

Lida Kheiri, https://orcid.org/0000-0001-9471-9902

Aida Kheiri, https://orcid.org/0000-0002-5311-1260

\section{Authors' Contributions}

All authors have participated in the study. The concept and study design were done by M.E. L.K. and A.K. participated in data collection and wrote the manuscript. F.H. and P.F.A. participated in data analysis. The study was revised critically by M.K. The final approval was performed by R.A.

\section{Acknowledgements}

This research did not receive any specific grant from any funding agency in the public, commercial, or not-for-profit sector.

\section{Conflict of Interest}

No potential conflict of interest relevant to this article was reported.

\section{References}

1. Valiense H, Barreto M, Resende RF, Alves AT, Rossi AM, Ma- 
vropoulos E, et al. In vitro and in vivo evaluation of strontiumcontaining nanostructured carbonated hydroxyapatite/sodium alginate for sinus lift in rabbits. J Biomed Mater Res B Appl Biomater 2016;104:274-82. https://doi.org/10.1002/jbm.b.33392

2. Al-Shabeeb MS, Al-Askar M, Al-Rasheed A, Babay N, Javed F, Wang HL, et al. Alveolar bone remodeling around immediate implants placed in accordance with the extraction socket classification: a three-dimensional microcomputed tomography analysis. J Periodontol 2012;83:981-7. https://doi.org/10.1902/ jop.2011.110569

3. Johnson K. A study of the dimensional changes occurring in the maxilla following tooth extraction. Aust Dent J 1969;14:241-4. https://doi.org/10.1111/j.1834-7819.1969.tb06001.x

4. Fugazzotto PA, Wheeler SL, Lindsay JA. Success and failure rates of cylinder implants in type IV bone. J Periodontol 1993;64:10857. https://doi.org/10.1902/jop.1993.64.11.1085

5. das Neves FD, Fones D, Bernardes SR, do Prado CJ, Neto AJ. Short implants--an analysis of longitudinal studies. Int J Oral Maxillofac Implants 2006;21:86-93.

6. Riben $\mathrm{C}$, Thor A. The maxillary sinus membrane elevation procedure: augmentation of bone around dental implants without grafts - a review of a surgical technique. Int J Dent 2012;2012:105483. https://doi.org/10.1155/2012/105483

7. Boyne PJ, James RA. Grafting of the maxillary sinus floor with autogenous marrow and bone. J Oral Surg 1980;38:613-6.

8. Summers RB. A new concept in maxillary implant surgery: the osteotome technique. Compendium 1994;15:152, 154-6, 158 passim; quiz 162.

9. Pawar SK, Pawar HS, Sapra N, Ghangas P, Sangwan R, Chawla R. Maxillary sinus floor elevation techniques with recent advances: a literature review. Asian Pac J Health Sci 2017;4:112-29. https://doi. org/10.21276/apjhs.2017.4.1.20

10. Călin C, Petre A, Drafta S. Osteotome-mediated sinus floor elevation: a systematic review and meta-analysis. Int J Oral Maxillofac Implants 2014;29:558-76. https://doi.org/10.11607/jomi.3206

11. Moraschini V, Uzeda MG, Sartoretto SC, Calasans-Maia MD. Maxillary sinus floor elevation with simultaneous implant placement without grafting materials: a systematic review and metaanalysis. Int J Oral Maxillofac Surg 2017;46:636-47. https://doi. org/10.1016/j.ijom.2017.01.021

12. Kolhatkar S, Bhola M, Thompson-Sloan TN. Sinus floor elevation via the maxillary premolar extraction socket with immediate implant placement: a case series. J Periodontol 2011;82:820-8. https:// doi.org/10.1902/jop.2010.100557

13. Schulte W, Heimke G. [The Tübinger immediate implant]. Quintessenz 1976;27:17-23. German.

14. Paolantonio M, Dolci M, Scarano A, d'Archivio D, di Placido G, Tumini V, et al. Immediate implantation in fresh extraction sockets. A controlled clinical and histological study in man. J Periodontol 2001;72:1560-71. https://doi.org/10.1902/jop.2001.72.11.1560

15. Liu H, Liu R, Wang M, Yang J. Immediate implant placement combined with maxillary sinus floor elevation utilizing the transalveolar approach and nonsubmerged healing for failing teeth in the maxillary molar area: a randomized controlled trial clinical study with one-year follow-up. Clin Implant Dent Relat Res 2019;21:462-72. https://doi.org/10.1111/cid.12783

16. Covani U, Cornelini R, Barone A. Bucco-lingual bone remodeling around implants placed into immediate extraction sockets: a case series. J Periodontol 2003;74:268-73. https://doi.org/10.1902/ jop.2003.74.2.268

17. Bassir SH, El Kholy K, Chen CY, Lee KH, Intini G. Outcome of early dental implant placement versus other dental implant placement protocols: a systematic review and meta-analysis. J Periodontol 2019;90:493-506. https://doi.org/10.1002/JPER.18-0338

18. Mello CC, Lemos CAA, Verri FR, Dos Santos DM, Goiato MC, Pellizzer EP. Immediate implant placement into fresh extraction sockets versus delayed implants into healed sockets: a systematic review and meta-analysis. Int J Oral Maxillofac Surg 2017;46: 1162-77. https://doi.org/10.1016/j.ijom.2017.03.016

19. Deng F, Zhang H, Zhang H, Shao H, He Q, Zhang P. A comparison of clinical outcomes for implants placed in fresh extraction sockets versus healed sites in periodontally compromised patients: a 1-year follow-up report. Int J Oral Maxillofac Implants 2010;25:1036-40.

20. Grandi T, Guazzi P, Samarani R, Grandi G. Immediate provisionalisation of single post-extractive implants versus implants placed in healed sites in the anterior maxilla: 1-year results from a multicentre controlled cohort study. Eur J Oral Implantol 2013;6:285-95.

21. Sun XL, Mudalal M, Qi ML, Sun Y, Du LY, Wang ZQ, et al. Flapless immediate implant placement into fresh molar extraction socket using platelet-rich fibrin: a case report. World J Clin Cases 2019;7:3153-9. https://doi.org/10.12998/wjcc.v7.i19.3153

22. Kadkhodazadeh M, Amid R. Implant success index (ISI): a new scoring system to evaluate the clinical outcomes of dental implants. J Clin Periodontol 2012;39(Suppl 13):209. https://doi.org/10.1111/ j.1600-051x-2012.01891.x

23. Sterne JA, Hernán MA, Reeves BC, Savović J, Berkman ND, Viswanathan M, et al. ROBINS-I: a tool for assessing risk of bias in non-randomised studies of interventions. BMJ 2016;355:i4919.

24. Bruschi GB, Crespi R, Capparè P, Bravi F, Bruschi E, Gherlone E. Localized management of sinus floor technique for implant placement in fresh molar sockets. Clin Implant Dent Relat Res 2013;15: 243-50. https://doi.org/10.1111/j.1708-8208.2011.00348.x

25. Barone A, Cornelini R, Ciaglia R, Covani U. Implant placement in fresh extraction sockets and simultaneous osteotome sinus floor elevation: a case series. Int J Periodontics Restorative Dent 2008; 28:283-9.

26. McCrea SJ. Trans-socket elevation/fracture/perforation of the sinus floor through the "infected" maxillary tooth socket to facilitate bicortical fixation of dental implants. Clin Adv Periodontics 2012;2:80-7. https://doi.org/10.1902/cap.2012.110025

27. Crespi R, Capparè $\mathrm{P}$, Gherlone EF. Electrical mallet in implants placed in fresh extraction sockets with simultaneous osteotome sinus floor elevation. Int J Oral Maxillofac Implants 2013;28:86974. https://doi.org/10.11607/jomi.2679

28. Ebenezer V, Balakrishnan R, Nathan S. Indirect sinus lift in immediate placent of implant - a case report. Biomed Pharmacol J 2015; 8:499-502. https://doi.org/10.13005/bpj/733

29. Mandelli F, Ghensi P, Vinci R, Mandelli G. Sinus floor elevation with crestal approach and immediately loaded post-extraction implants. J Indiana Dent Assoc 2013;92:22-4; quiz 25.

30. Falcón B. Treatment of post-extraction implant with internal sinus floor elevation: a case report. J Implant Adv Clin Dent 2015;7:115.

31. Taschieri S, Del Fabbro M. Postextraction osteotome sinus floor elevation technique using plasma-rich growth factors. Implant Dent 2011;20:418-24. https://doi.org/10.1097/ID.0b013e3182354063

32. Chen Y, Yuan S, Zhou N, Man Y. Transcrestal sinus floor augmentation with immediate implant placement applied in three types of fresh extraction sockets: a clinical prospective study with 1-year follow-up. Clin Implant Dent Relat Res 2017;19:1034-43. https:// doi.org/10.1111/cid.12529

33. Artzi Z, Parson A, Nemcovsky CE. Wide-diameter implant placement and internal sinus membrane elevation in the immediate postextraction phase: clinical and radiographic observations in 12 consecutive molar sites. Int J Oral Maxillofac Implants 2003;18: 242-9.

34. Fugazzotto PA. Sinus floor augmentation at the time of maxillary molar extraction: technique and report of preliminary results. Int $\mathrm{J}$ Oral Maxillofac Implants 1999;14:536-42.

35. Canullo L, Iurlaro G, Iannello G. Double-blind randomized controlled trial study on post-extraction immediately restored implants using the switching platform concept: soft tissue response. Preliminary report. Clin Oral Implants Res 2009;20:414-20. https://doi. org/10.1111/j.1600-0501.2008.01660.x 
36. Ribeiro FS, Pontes AE, Marcantonio E, Piattelli A, Neto RJ, Marcantonio E Jr. Success rate of immediate nonfunctional loaded single-tooth implants: immediate versus delayed implantation. Implant Dent 2008;17:109-17. https://doi.org/10.1097/ ID.0b013e318166cb84

37. Wood DL, Hoag PM, Donnenfeld OW, Rosenfeld LD. Alveolar crest reduction following full and partial thickness flaps. J Periodontol 1972;43:141-4. https://doi.org/10.1902/jop.1972.43.3.141

38. Chrcanovic BR, Albrektsson T, Wennerberg A. Flapless versus conventional flapped dental implant surgery: a meta-analysis. PLoS One 2014;9:e100624. https://doi.org/10.1371/journal. pone. 0100624

39. Carranza FA Jr, Itoiz ME, Cabrini RL, Dotto CA. A study of periodontal vascularization in different laboratory animals. J Periodontal Res 1966;1:120-8. https://doi.org/10.1111/j.1600-0765.1966. tb01851.x

40. Divakar TK, Gidean Arularasan S, Baskaran M, Packiaraj I, Dhineksh Kumar N. Clinical evaluation of placement of implant by flapless technique over conventional flap technique. J Maxillofac Oral Surg 2020;19:74-84. https://doi.org/10.1007/s12663-01901218-9

41. Mazzocco F, Jimenez D, Barallat L, Paniz G, Del Fabbro M, Nart $\mathrm{J}$. Bone volume changes after immediate implant placement with or without flap elevation. Clin Oral Implants Res 2017;28:495-501. https://doi.org/10.1111/clr.12826

42. Campelo LD, Camara JR. Flapless implant surgery: a 10-year clinical retrospective analysis. Int J Oral Maxillofac Implants 2002;17: 271-6.

43. Cai H, Liang X, Sun DY, Chen JY. Long-term clinical performance of flapless implant surgery compared to the conventional approach with flap elevation: a systematic review and meta-analysis. World J Clin Cases 2020;8:1087-103. https://doi.org/10.12998/wjcc. v8.i6.1087

44. Romero-Ruiz MM, Mosquera-Perez R, Gutierrez-Perez JL, TorresLagares D. Flapless implant surgery: a review of the literature and 3 case reports. J Clin Exp Dent 2015;7:e146-52. https://doi. org/10.4317/jced.51985

45. Albrektsson T, Isidor F. Consensus report of session IV. In: Lang NP, Karring T, eds. Proceedings of the 1st European Workshop on Periodontology. Batavia (IL): Quintessence Publishing; 1994:365-

46. Emmerich D, Att W, Stappert C. Sinus floor elevation using osteotomes: a systematic review and meta-analysis. J Periodontol
2005;76:1237-51. https://doi.org/10.1902/jop.2005.76.8.1237

47. Chiarella G, Leopardi G, De Fazio L, Chiarella R, Cassandro C, Cassandro E. Iatrogenic benign paroxysmal positional vertigo: review and personal experience in dental and maxillo-facial surgery. Acta Otorhinolaryngol Ital 2007;27:126-8.

48. Silva LD, de Lima VN, Faverani LP, de Mendonça MR, Okamoto R, Pellizzer EP. Maxillary sinus lift surgery-with or without graft material? A systematic review. Int J Oral Maxillofac Surg 2016;45: 1570-6. https://doi.org/10.1016/j.ijom.2016.09.023

49. Yan M, Liu R, Bai S, Wang M, Xia H, Chen J. Transalveolar sinus floor lift without bone grafting in atrophic maxilla: a meta-analysis Sci Rep 2018;8:1451. https://doi.org/10.1038/s41598-018-19515-7

50. Kadkhodazadeh M, Moscowchi A, Zamani Z, Amid R. Clinical and radiographic outcomes of a novel transalveolar sinus floor elevation technique. J Maxillofac Oral Surg 2020. https://doi. org/10.1007/s12663-020-01439-3 [Epub ahead of print]

51. Rammelsberg P, Kilian S, Büsch C, Kappel S. The effect of transcrestal sinus-floor elevation without graft on the long-term prognosis of maxillary implants. J Clin Periodontol 2020;47:640-8. https://doi.org/10.1111/jcpe. 13278

52. Parra M, Olate S, Cantín M. Clinical and biological analysis in graftless maxillary sinus lift. J Korean Assoc Oral Maxillofac Surg 2017;43:214-20. https://doi.org/10.5125/jkaoms.2017.43.4.214

53. Duan DH, Fu JH, Qi W, Du Y, Pan J, Wang HL. Graft-free maxillary sinus floor elevation: a systematic review and metaanalysis. J Periodontol 2017;88:550-64. https://doi.org/10.1902/ jop.2017.160665

54. Si MS, Zhuang LF, Gu YX, Mo JJ, Qiao SC, Lai HC. Osteotome sinus floor elevation with or without grafting: a 3-year randomized controlled clinical trial. J Clin Periodontol 2013;40:396-403. https://doi.org/10.1111/jcpe.12066

How to cite this article: Ekhlasmandkermani M, Amid R, Kadkhodazadeh M, Hajizadeh F, Abed PF, Kheiri L, et al. Sinus floor elevation and simultaneous implant placement in fresh extraction sockets: a systematic review of clinical data. J Korean Assoc Oral Maxillofac Surg 2021;47:411-426. https://doi. org/10.5125/jkaoms.2021.47.6.411 